\title{
Pembuatan Sistem Kontrol Sliding Door untuk Rumah Tinggal
}

\author{
The Making Off Controlling System to Sliding Door for House
}

\author{
Sir Anderson \\ Jurusan Teknik Mesin, Politeknik Negeri Padang \\ Telp. 0751-72590 Fax. 0751-72576
}

\begin{abstract}
The sliding door is a type of door that works by sliding the door to the right or to the left. The sliding door is a type of door that is suitable for use in a room with small volume, because the sliding door does not require a large space. lack the sliding door when the door has been closed, lack the sliding door when the door has been closed, there still exists a gap between the open doors and walls so that air can be in and out freely. with the construction of the door using the hinge mechanism, can minimize these conditions. To make the sliding door works automatically, the authors make a set of control system that uses an analog system and the concept of open-loop control system. "dc motor" is used as drive for the door and "central lock actuator" as locking doors. On the control circuit voltage source used is equal to $12 \mathrm{~V}$.

Control circuit components used are double circuit push button (NO and NC), 12V relay 8 feet, limits switches, motor DC of power windows, central lock actuator. The components were assembled for the purpose of changing the polarity of the DC motor is regulated by a relay mechanism. By changing the polarity of the dc motor, the motor can rotate to the left and to the right, so the door is connected to the motor would be moves to open and close according to the motor movement.
\end{abstract}

Keyword: Sliding Door;automatic;Relay;analog system;open loop control system;power window

\section{PENDAHULUAN}

Diera globalisasi sekarang ini perkembangan ilmu dan teknologi berkembang dengan pesat. Perkembangan teknologi itu dapat dilihat dari banyaknya peralatan otomatis yang digunakan untuk mempermudah pekerjaan manusia. Selain otomatis, peralatan tersebut diharapkan mampu bekerja dengan mengoptimalkan ruangan yang tersedia untuk peralatan tersebut. Salah satu contoh alat yang cara kerjanya dapat dibuat otomatis dan mampu bekerja dengan mengoptimalkan ruangan yang tersedia yaitu pintu geser. Pintu geser merupakan jenis pintu yang sangat cocok untuk digunakan pada ruangan yang bervolume kecil, karena pintu geser tidak memerlukan ruang gerak yang beser.

Akan tetapi pintu geser atau sliding door yang ada saat ini masih belum efektif dalam penggunaannya dikarenakan masih adanya kerenggangan antara pintu dan dinding. Untuk itu dibuatlah suatu konsep baru pada sliding door agar tidak adanya kerenggangan antara pintu dan dinding. Adapun judul tulisan ini adalah "Pembuatan Sistem Kontrol Sliding Door Untuk Rumah Tinggal"

Alasan untuk mengangkat judul "Pembuatan Sistem Kontrol Sliding Door Untuk Rumah Tinggal"yaitu:

1. Mengembangkan konsep sliding door yang telah ada. Sliding door tersebut memiliki kekurangan yaitu setelah pintu tertutup, masih adanya kerenggangan antara pintu dan dinding. Oleh karena itu, Penulis berencana membuat suatu rancangan konstruksi sliding door dengan konsep yang berbeda agar tidak adanya kerenggangan antara dinding dan pintu.

2. Mempelajari lebih lanjut mengenai sistem kontrol pada suatu instrumen khususnya pada sliding door

Tujuan Penulisan

1. Dapat membuat sistem kontrol pada sliding door 
2. Mengubah konsep sliding door yang telah ada menjadi lebih efektif (tidak ada celah antara pintu dan dinding saat dalam posisi tertutup)

Adapun dalam tulisan ini penulis membatasi pembahasannya mengenai pembuatan sistem kontrol pada sliding door.

yang berjudul "Pembuatan Sistem Kontrol Sliding Door Untuk Rumah Tinggal ini, Penulis berharap tulisan ini dapat bermanfaat dan bisa dijadikan referensi yang layak bagi pembaca. Sehingga rancangan konstruksi pada pintu geser secara otomatis ini dapat digunakan pada instrumen-instrumen yang lain.

\section{Jenis-jenis Pintu}

Ada beberapa jenis pintu untuk meghubungkan suatu ruangan dengan ruangan yang lain, yaitu:

\section{Pintu Swing}

Pintu ini dapat membuka dan menutup dengan cara didorong ke depan atau ditarik ke belakang dengan putaran satu arah maupun dua arah. Kelebihan dari pintu ini yaitu, pemasangan dan perawatan engselnya lebih mudah. Namun pintu ini memiliki kekurangan karena dibutuhkan ruang untuk mengayunkan pintu pada saat dibuka.

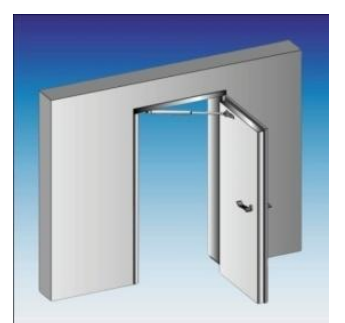

Gambar 1. Pintu Swing ${ }^{6}$

\section{Pintu Geser}

Pintu jenis ini sering disebut juga dengan sliding door. Cara kerja pintu ini yaitu dengan menggeser pintu ke kanan atau ke kiri. Pintu geser ini biasanya digunakan pada ruangan yang sempit karena tidak memerlukan ruang untuk mengayunkan pintu seperti pada pintu swing. Di samping kelebihan tersebut, masih terdapat kekurangan pada pintu jenis ini. Yaitu pada saat pintu telah tertutup, seperti terlihat pada gambar 2, masih adanya celah terbuka di antara pintu dan dinding sehingga ini memberikan kesan yang kurang efektif bila digunakan pada ruangan yang memiliki sistem pendingin (air conditioner)

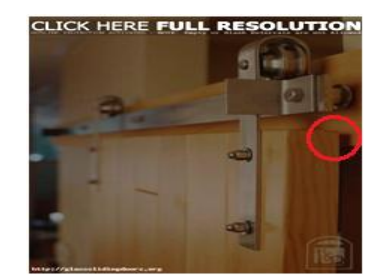

Gambar 2. Celah Pada Saat Pintu Tertutup $^{8}$

3. Pintu Lipat

Pintu ini sering disebut juga dengan folding door. Cara kerjanya pun tidak berbeda dengan pintu geser, yaitu dengan cara digeser ke samping dengan menggunakan bantalan rel. Namun perbedaanya folding door ini dilipat antara daun pintu yang satu dengan yang lainnya. Jenis pintu ini biasanya sering digunakan pada ruang keluarga yang menghadap ke taman belakang atau pada pintu garasi. Kelebihannya yaitu, dapat dibuka dan ditutup lebih lebar dibandingkan dengan pintu swing dan pintu geser terlihat pada (gambar 2). Sedangkan kekurangannya dapat dilihat pada (gambar 3) yaitu, pintu lipat ini memerlukan spasi vertikal untuk tempat daun-daun pintu melipat ke dalam.

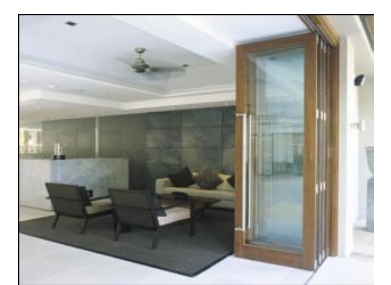

Gambar 3. Pintu Lipat Terbuka ${ }^{10}$ 4. Pintu Putar Otomatis

Pintu putar otomatis atau revolving door digunakan pada mall, hotel, dan gedung perkantoran. Pintu ini akan berputar secara otomatis saat terdapat gerakan orang yang hendak memasuki ruangan. Kelebihan pintu putar 
otomatis ini yaitu, suhu di dalam ruangan akan tetap terjaga karena tidak bercampur dengan suhu yang ada di luar ruangan. Pintu jenis ini memiliki kekurangan yaitu, akan terjadi antrian jika terdapat banyak orang yang akan keluar-masuk ruangan.

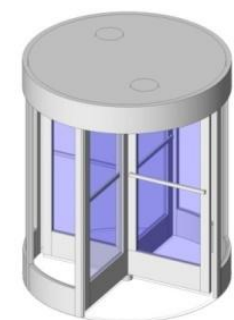

Gambar 4. Pintu Putar ${ }^{11}$

\section{Rangkaian Listrik}

Listrik Dinamis adalah listrik yang dapat bergerak. Salah satu contoh listrik dinamis adalah pada baterai. Baterai mempunyai kutub positif dan kutub parallel. Kutub positif (+) adalah ujung baterai dengan tonjolan kecil. Sementara, kutub parallel (-) adalah ujung baterai yang rata (biasanya mengilap). Jika kedua kutub dihubungkan dengan kabel, maka akan menghasilkan aliran listrik pada komponen listrik seperti contohnya lampu

\section{1). Rangkaian Seri}

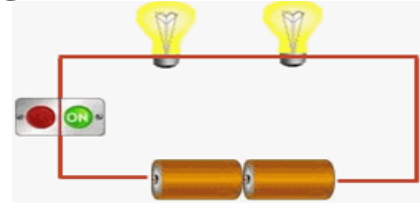

Gambar 5. Rangkaian Seri Lampu ${ }^{12}$

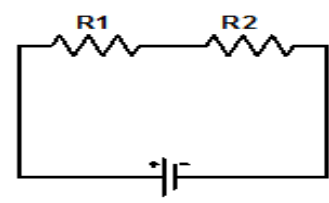

Gambar 6. Rangkaian Seri Resistor

Pada rangkaian seri apabila salah satu lampu diputuskan ( mati ) maka lampu yang lain juga juga akan mati. Perhatikan gambar disamping jika saklar dimatikan maka kedua buah lampu akan mati semua. Besar hambatan total yang terdapat pada rangkaian diatas yaitu

$$
\boldsymbol{R} t o t=R A+R B
$$

Dalam rangkaian seri, besar tegangan sumber, Vsumber, adalah sama dengan jumlah tegangan pada lampu A dan B,

$$
\text { Vsumber }=V A+V B
$$

Karena arus $I$ yang melalui lampu-lampu tersebut sama besar, maka $V A=I . R A$ dan $V B=I . R B$. Oleh karena itu,

Vsumber $=I . R A+I . R B$ atau Vsumber $=$ $I(R A+R B)$.

\section{2). Rangkaian Paralel}

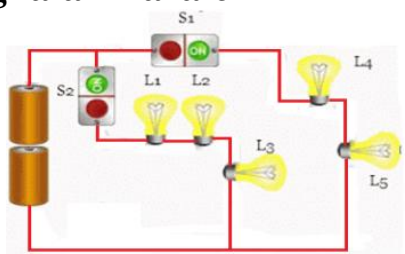

Gambar 7. Rangkaian Paralel Lampu ${ }^{12}$

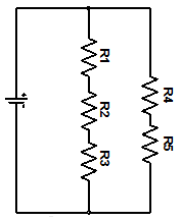

Gambar 8. Rangkaian Paralel Resistor

Rangkaian parallel (Gambar 9) terbentuk jika dua buah bola lampu atau lebih dihubungkan secara berjajar. Kutub lampu sejenis dihubungkan ke kutub baterai yang sama. Pada rangkaian parallel jika salah satu lampu diputuskan (mati), lampu yang lainya tetap menyala. Hal ini terjadi karena lampu yang lain masih terhubung dengan sumber arus listrik. Perhatikan gambar di samping, jika saklar 1 (s1) dimatikan maka yang mati hanya lampu 4 dan 5 sedangkan lampu 1, 2, dan 3 tetap menyala. Jika saklar 2 (s2) dimatikan yang mati hanya lampu 1, 2, dan 3 sedangkan lapu 4 dan 5 tetap menyala.

Pada (Gambar 10) tiga buah resistor disusun secara paralel dan ujungujung ketiga resistor dihubungkan secara bersama-sama ke sumber tegangan, sehingga arus memiliki tiga jalan yang berbeda untuk melewati tiap-tiap resistor.

.Hambatan pengganti pada rangkaian paralel dapat ditentukan dengan persamaan :

$$
\frac{1}{R_{\text {TOTAL. }}}=\frac{1}{R 1}+\frac{1}{R 2}+\frac{1}{R 3}
$$




\section{3). Rangkaian Campuran}

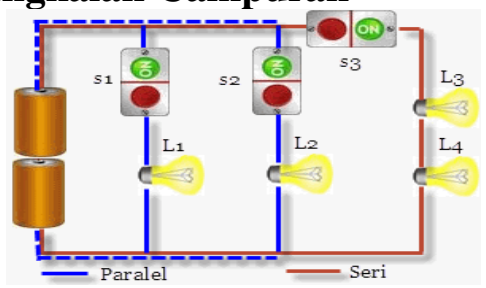

Gambar 9. Rangkaian Campuran Lampu ${ }^{12}$

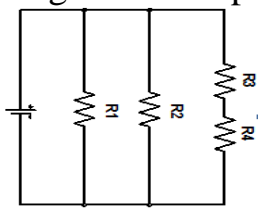

Gambar 10. Rangkaian Campuran Resistor Rangkaian campuran merupakan gabungan dari rangkaian seri dan rangkaian parallel. (Perhatikan gambar 11) rangkaian listrik dengan garis merah menunjukkan rangkaian seri, jika saklar 3 dimatikan maka lampu 4 dan lampu 5 akan mati. Sedangkan rangkaian listrik dengan garis biru menunjukan rangkaian parallel. Jika saklar 1 dimatikan lampu yang mati hanya lampu 1 saja, demikian juga jika saklar 2 dimatikan lampu yang mati hanya lampu 2 saja.

Pada gambar.12 terlihat bahwa arus (arah konvensional) mengalir dari kutub positif baterai kemudian terpecah dan bercabang melewati $R_{\mathbf{1}}$ dan $R_{\mathbf{2}}$, kemudian menyatu, lalu terpecah dan bercabang lagi melewati $\mathrm{R}_{\mathbf{3}}$ dan $\mathrm{R}_{\mathbf{4}}$, lalu menyatu kembali dan masuk ke terminal negatif baterai. Ada lebih dari satu jalur untuk dialiri arus (bukan seri), tetapi juga ada lebih dari dua titik yang digunakan bersama oleh komponen pada rangkaian itu (bila anda perhatikan ada tiga titik/node) sehingga juga bukan rangkaian paralel.

\section{Sistem Kontrol}

\section{1). Pengertian Sistem Kontrol}

Sistem automat (sistem kendali) telah memegang peranan yang sangat penting dalam perkembangan ilmu dan teknologi.

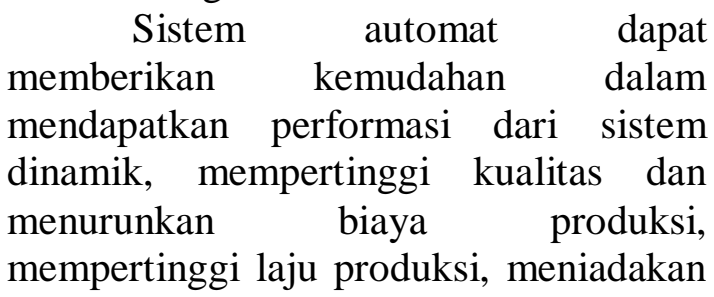

pekerjaan - pekerjaan rutin dan membosankan yang harus dilakukan oleh manusia, dan sebagainya.

Pengertian sistem automat itu sendiri adalah proses pengaturan / pengendalian terhadap satu atau beberapa besaran (automati, parameter) sehingga berada pada suatu harga atau dalam suatu rangkuman harga (range) tertentu. Dalam istilah lain disebut juga teknik pengaturan, sistem pengendalian atau sistem pengontrolan. Secara umum sistem automat dapat dikelompokkan sebagai berikut :

1. Dengan operator (manual) dan otomatik.

2. Jaringan tertutup (closed-loop) dan jaringan terbuka (open-loop).

3. Kontinu (analog) dan diskontinu (digital, diskrit).

4. Servo dan regulator.

5. Menurut sumber penggerak : elektris, automatic (udara, angin), hidarulis (cairan), dan mekanis. (76utomat otomatik teori dan penerapan : 1994)

\section{2). Jenis - Jenis Pengontrolan}

a. Pengontrolan Manual

Pengontrolan secara manual ialah pengontrolan yang dilakukan secara langsung oleh manusia. Di dalam pengontrolan ini, peranan

b. Pengontrolan Otomatis

Pengontrolan otomatis adalah pengontrolan suatu besaran proses apabila terjadi penyimpangan atau deviasi maka akan terjadi suatu usaha perbaikan secara otomatis sehingga dapat membatasi penyimpangan atau deviasi tersebut dari nilai yang dikehendaki.

\section{3). Penggolongan Sistem Pengontrolan}

Suatu sistem pengaturan dapat berupa suatu sistem yang sederhana dimana terdiri dari satu proses dan satu komponen pengatur yang sering dinamai suatu loop pengaturan proses, dan dapat pula berupa suatu sistem yang rumit dimana proses itu terdiri dari beberapa loop pengaturan.

\section{a. Pengontrolan Loop Terbuka}


Pengontrolan loop terbuka adalah sistem kontrol yang keluarannya tidak mempengaruhi proses pengontrolan. Jadi pada sistem kontrol loop terbuka, sinyal keluaran (output) tidak diumpan balikan untuk dibandingkan ke sinyal masukan (input).

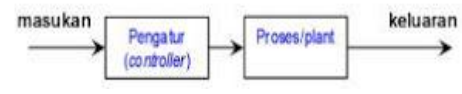

Gambar 11. Sistem pengendalian lup terbuka $^{13}$

\section{b). Pengontrolan Loop Tertutup dengan Feed Forward}

Pengontrolan loop tertutup dengan feed forward adalah sistem kontrol yang keluarannya tergantung masukan yang melalui sistem dan juga dipengaruhi oleh masukan secara langsung. Pengaturan ini dilakukan dengan mengukur input yang lainnya dan dibandingkan dengan harga yang diinginkan. Pengaturan feed forward biasanya mempunyai lebih dari satu masukan dengan keluaran

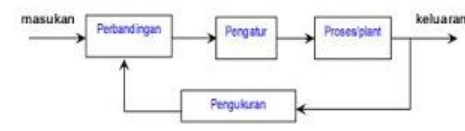

Gambar 12. Sistem pengendalian lup tertutup $^{13}$

\section{Motor DC}

\section{1). Pengertian Motor DC}

Motor DC merupakan jenis motor yang menggunakan tegangan searah sebagai sumber tenaganya. Dengan memberikan beda tegangan pada kedua terminal tersebut, motor akan berputar pada satu arah, dan bila polaritas dari tegangan tersebut dibalik maka arah putaran motor akan terbalik pula. Polaritas dari tegangan yang diberikan pada dua terminal menentukan arah putaran motor sedangkan besar dari beda tegangan pada kedua terminal menentukan kecepatan motor.

Motor DC memiliki 2 bagian dasar :

1. Bagian yang tetap/stasioner yang disebut stator. Stator ini menghasilkan medan magnet, baik yang dibangkitkan dari sebuah koil (elektro magnet) ataupun magnet permanen.
2. Bagian yang berputar disebut rotor. Rotor ini berupa sebuah koil dimana arus listrik mengalir.

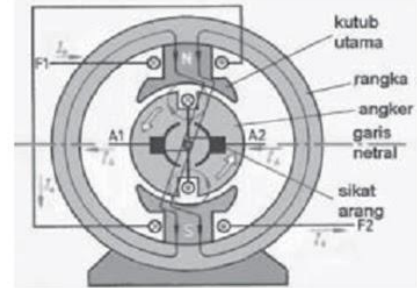

Gambar 13. Kontruksi Motor DC ${ }^{14}$

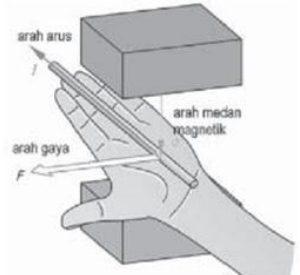

Gambar 14. Penentuan Arah Gaya ${ }^{14}$

\section{2). Mengatur Arah Putaran Motor DC}

Motor DC bekerja menggunakan arus searah dalam membangkitkan medan putarnya, maka untuk membalik arah putaran motor DC adalah dengan membalik arah medan putarnya, arah medan putar dapat dibalik dengan mengubah arah arus yang mengalir pada motor DC seperti gambar berikut:
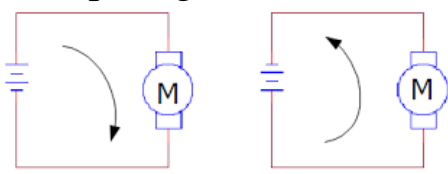

Gambar 15. Dasar Pengaturan Arah Putar Motor $^{16}$

Pada gambar di atas mengubah arah arus dapat dilakukan dengan membalik polaritas (kutub) sumber arus, perubahan polaritas menyebabkan perubahan arah arus dalam motor sehingga arah medan putar akan berubah dan menyebabkan motor berputar ke arah yang berlawanan. Untuk mempermudah pembalikan arah arus dapat dengan menambahkan saklar 2 buah SPDT yang dirangkai sebagaimana gambar berikut: 


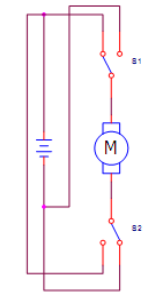

Gambar 16. Pengatur Arah Dengan Menggunakan Saklar ${ }^{16}$

Pada gambar di atas, dengan mengubah posisi saklar S1 dan S2 maka arah arus akan berubah, untuk mengembalikan putarannya tinggal mengembalikan posisi saklar S1 dan S2 ke posisi semula.

\section{Door Lock Actuator}

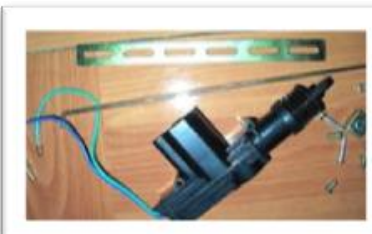

Gambar 17. Actuator Door Lock ${ }^{17}$

Door lock actuator adalah Berfungsi sebagai penarik dan pendorong tuas pengunci pintu mobil, yang digerakan oleh motor listrik DC, yang dapat bergerak/berputar ke kanan dan ke kiri.

Actuator utama Berfungsi sebagai pengendali atau sentral dari semua actuator, artinya jika actuator digerakkan secara manual (tarik atau dorong) maka semua actuator yang lain akanbergerak dengan gerakan yang sama, oleh karena itu ditempatkan di pintu pengemudi.

Komponen-komponen dari door lock actuator adalah sebagai berikut :
a. Motor
b. Gears
c. Pinion meshes
d. Armature rod
e. Changeover contact (saklar

\section{Push Button \\ Pengertian Push Button}

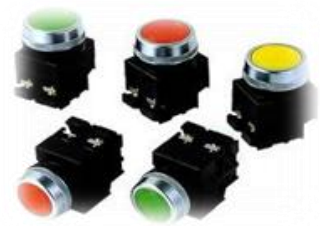

Gambar 18. Push Button ${ }^{18}$
Untuk menggerakan suatu mesin diperlukan suatu alat yang sangat banyak jenis dan ragamnya, salah satunya adalah Push Button atau saklar tekan.Pada Push Button (PB), terdapat kontak-kontaknya, yang berupa normaly close (NC) dan normaly open (NO), atau ada juga PB yang memiliki jumlah kontak lebih banyak.

\section{Relay}

Relay adalah komponen listrik yang bekerja berdasarkan prinsip induksi medan elektromagnetis. Jika sebuah penghantar dialiri oleh arus listrik, maka di sekitar penghantar tersebut timbul medan magnet. Medan magnet yang dihasilkan oleh arus listrik tersebut selanjutnya diinduksikan ke logam ferromagnetis

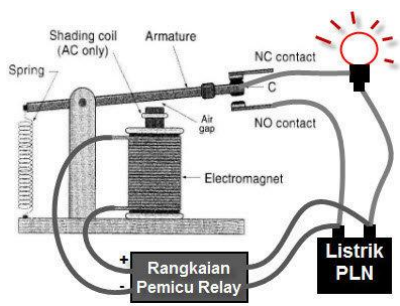

Gambar 19. Komponen Relay ${ }^{19}$

\section{Limit Switch}

Limit switch merupakan jenis saklar yang dilengkapi dengan katup yang berfungsi menggantikan tombol. Prinsip kerja limit switch diaktifkan dengan penekanan pada tombolnya pada batas/daerah yang telah ditentukan sebelumnya sehingga terjadi pemutusan atau penghubungan rangkaian dari rangkaian tersebut. Limit switch memiliki 2 kontak yaitu NO (Normally Open) dan kontak NC (Normally Close) dimana salah satu kontak akan aktif jika tombolnya tertekan. Konstruksi dan simbol limit switch dapat dilihat seperti gambar di bawah.

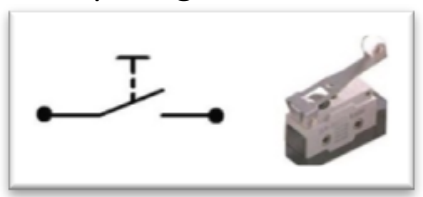

Gambar 20. Simbol Dan Bentuk Limit Switch $^{4}$ 


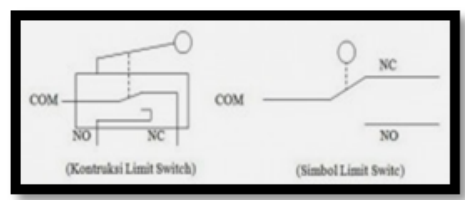

Gambar 21. Konstruksi dan Simbol Limit Switch ${ }^{4}$

\section{METODOLOGI}

\section{Bahan-bahan yang Dibutuhkan Konstruksi Sliding Door}

Adapun bahan-bahan yang dibutuhkan untuk membuat sliding door ini adalah sebagai berikut:

1). Pipa baja persegi, berfungsi sebagai bahan untuk membuat rel.

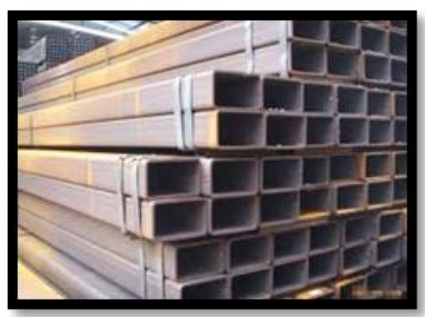

Gambar 22. Pipa Baja Persegi

2). Bantalan Gelinding.

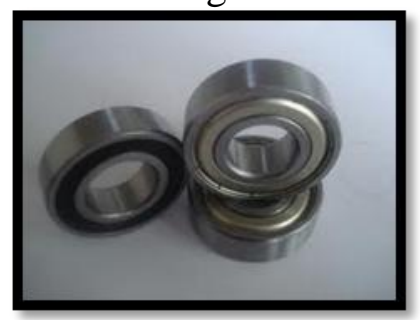

Gambar 23. Bantalan Gelinding

3). Baja profil L yang berfungsi sebagai engsel.

4). Baja profil $\mathrm{C}$ yang berfungsi sebagai kedudukan bantalan.

5). Pelat baja dengan ketebalan $5 \mathrm{~mm}$ yang juga berfungsi sebagai engsel.

6). Pintu swing dan kusen.

7). Baut pengikat.

\section{Model Rancangan Sliding door}
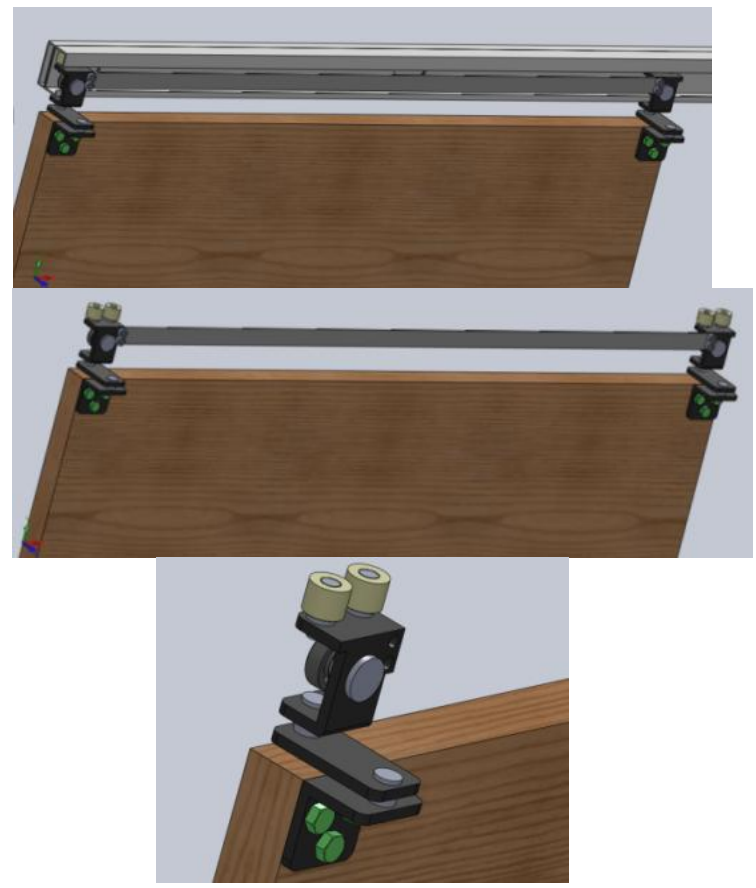

Gambar 24. Model Rancangan Sliding Door

\section{Peralatan dan Bahan yang} Dibutuhkan Dalam Pembuatan Sistem Kontrol Sliding Door.

1) Push Button, berfungsi untuk mengontrol kondisi on atau off rangkaian listrik

2) Relay berfungsi untuk mengontrol aliran listrik seperti menahan aliran atau arus listrik pada rangkaian listrik.

3) Limit Switch berfungsi untuk memutuskan arus dari rangkaian.

4) Adaptor adalah komponen listrik yang berfungsi untuk maikan dan menurunkan tegangan dan arus.

5) Motor DC berfungsi sebagai media penggerak pintu.

6) Obeng berfungsi sebagai pengikat baut pada sambungan kabel

7) Tang potong berfungsi untuk memotong kabel 


\section{HASIL DAN PEMBAHASAN}

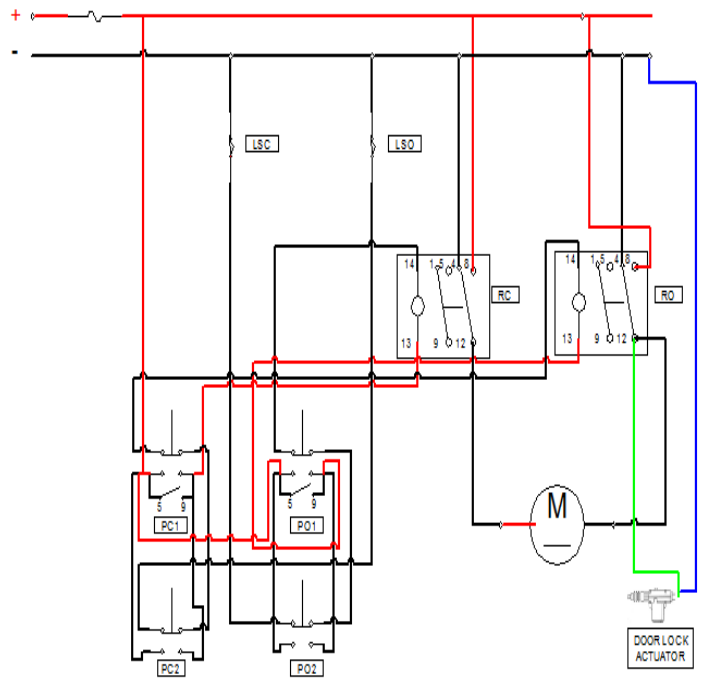

Relay komponen listrik yang juga berfungsi sebagai penyambung dan pemutus arus, relay pada rangkaian ini sering disebut dengan istilah relay delapan kaki, maksudnya adalah pada relay ini terdapat delapan poin/terminal penghubung. Pada relay delapan kaki ini terdapat satu coil dan 2 kontak normally open yaitu dalam keadaan tidak bekerja membuka dan dalam keadaan bekerja menutup (menghubungkan dua titik terminal).

3.

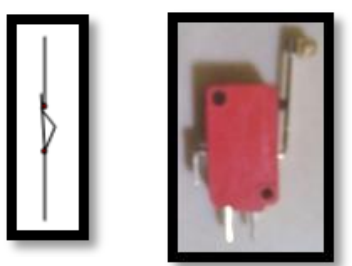

Limits Switch adalah komponen listrik yang berfungsi sebagai penyambung dan pemutus arus, pada limits switch terdapat katup sebagai pengganti tombol.

4.
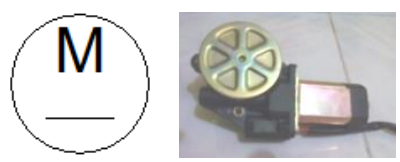

Motor DC adalah jenis motor yang menggunakan tegangan searah sebagai sumber tenaganya. Dengan memberikan beda tegangan pada kedua terminal tersebut, motor akan berputar pada satu arah, dan bila

\section{Keterangan Simbol :}

1.

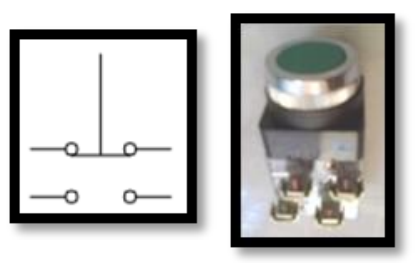

Push Button Double Circuit (tombol tekan) adalah alat yg berfungsi pemberi sinyal masukan pada rangkaian listrik. Push button daouble circuit terdiri dari contact poin $\mathrm{NO}$ (normally open) dan NC (normally close).

2.
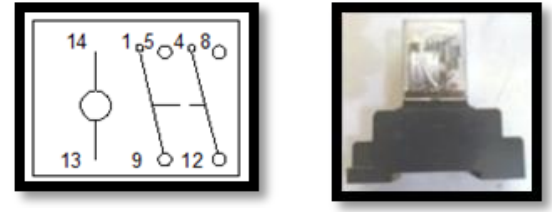

polaritas dari tegangan tersebut dibalik maka arah putaran motor akan terbalik pula,

5.
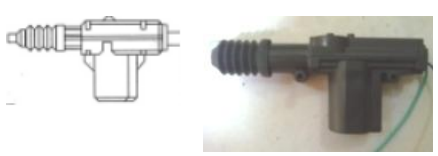

Door Lock Actuator berfungsi sebagai penarik dan pendorong tuas pada pintu, door lock actuator ini digerakkan oleh motor dc yang dapat bergerak kekiri dan kekanan.

6. PO1 : Push Button Open 1 (Push buton yang digunakan untuk membuka pintu)

7. PO2 : Push Button Open 2 (Push button yang digunakan untuk membuka pintu)

8. PC1 : Push Button Close 1 (Push button yang digunakan untuk menutup pintu)

9. PC2 : Push Button Close 2 (Push button yang digunakan untuk menutup pintu)

10. RO: Relay Open (Relay yang digunakan sebagai pengontrol untuk membuka pintu)

11. RC: Relay Close (Relay yang digunakan sebagai pengontrol untuk menutup pintu) 
12. LSO : Limits Switch Open (Pemutus aliran listrik pada saat pintu terbuka)

13. LSC : Limit Switch Close (Pemutus aliran listrik pada saat pintu tertutup)

\section{Prinsip Kerja Rangkaian Kontrol}

Pada rangkaian kontrol ini output yang dihasilkan adalah membuka dan menutup sliding door

\section{Membuka Pintu}

1) Ketika PO1 ditekan maka aliran arus positif $(+)$ dari sumber akan mengalir menuju coil pada relay (RO) dan kelurannya menuju kontak NC pada PC1 dan aliran arus diteruskan ke kontak NC pada PC2 selanjutnya mengalir menuju limits switch LSO yang berada pada kondisi normally close lalu ke arus negaif sumber ( - ), dengan itu maka secara otomatis coil pada relay RO akan aktif.

2) Setelah coil aktif, contak point yang semula NC (normally close) akan berpindah atau lebih tepatnya terminal (1 - 9) yang semulanya terhubung menjadi terputus dan bertukar menjadi terminal (5 - 9) yang terhubung, begitu juga pada terminal (4 - 12) yang semulanya terhubung menjadi terputus dan terminal $(8-12)$ menjadi terhubung.

3) Setelah relay aktif maka aliran listrik menjadi terkunci, hal ini dikarenakan kontak NC pada push button dihungkan ke terminal $(5-9)$ pada relay.

4) Selanjutnya arus positif dari sumber mengalir melalui relay pada terminal $(8-12)$ menuju ke katup negatif dari motor, sedangkan katup positif motor telah terhubung pada arus negatif dari sumber, dengan ini maka motor dc akan aktif dan berutar searah jarum jam.

5) Lalu pada door lock aktuator, aliran arus pada terminal $(8-12)$ juga menuju pada katup negatif dari door lock aktuator, dan katup positifnya telah tehubung pada arus negatif dari sumber, dengan ini maka door lock aktuator akan aktif dan menarik tuas kedalam.

6) Dengan kondisi motor aktif, dan sisi pintu yang telah dihubungkan dengan motor, maka otomotais pintu akan bergerak membuka sampai batas dimana bagian pintu menyentuh limit switch yang telah dipasang pada jarak buka tertentu dari pintu, dengan tertekannya limit switch maka seuruh aliran listrik pada rangkaian akan terputus.

\section{Menutup Pintu}

1) Ketika $\mathrm{PO} 2$ ditekan maka aliran arus positif $(+)$ dari sumber akan mengalir menuju coil pada relay (RC) dan kelurannya menuju kontak NC pada PC2 dan aliran arus listrik diteruskan ke kontak NC pada PC1 dan selanjutnya mengalir menuju limits switch LSC yang juga berada pada kondisi normally close lalu berakhir di sumber negaif ( - ), dengan itu maka secara otomatis coil pada relay $\mathrm{RO}$ akan aktif.

2) Setelah coil aktif, maka terjadi perpindahan contak point yang semulanya pada posisi NC (normally close) atau lebih tepatnya terminal (1 - 9) yang semulanya terhubung menjadi terputus dan bertukar menjadi terminal (5 - 9) yang terhubung, begitu juga pada terminal (4 - 12) yang semulanya terhubung menjadi terputus dan terminal $(8-$ 12) menjadi terhubung.

3) Setelah relay aktif maka aliran listrik menjadi terkunci, hal ini dikarenakan kontak NC pada push button dihungkan ke terminal $(5-9)$ pada relay.

4) Pada kondisi coil aktif, arus positif (+) masuk ke katub positif (+) dari mator dc, sedangkan katup negatif ( ) dari motor telah terhubung arus negatif ( - ) dari sumber melalui RO (Relay Open). Dengan kondisi ini maka motor akan kembali aktif 
dengan arah putaran berlawanan jarum jam.

5) Dengan kondisi ini maka pintu akan bergerak menutup, sampai batas dimana sisi ujung pintu menyentuh limit switch sehinga memutuskan aliran listrik pada rangkaian.

6) Kondisi diatas juga berlaku jika menekan PO2 (Push Button Open 2) dan PC2 (Push Button Close 2), hal ini di karenakan kontak NC (normally close) pada PO2 telah di couple dengan kontak NC (normally close) pada PO1. Lalu pada kontak NC pada PC2 juga dicouple dengan kontak NC pada PC1.

\section{Prakitan Komponen Kontrol}

Berdasarkan rangkaian diatas maka dapat dilakukan proses perakitan komponen kontrolnya sebagai berikut :

1. Arus positif dihubungkan dengan masukan NO (normally open) dari PC1 (push button close 1).
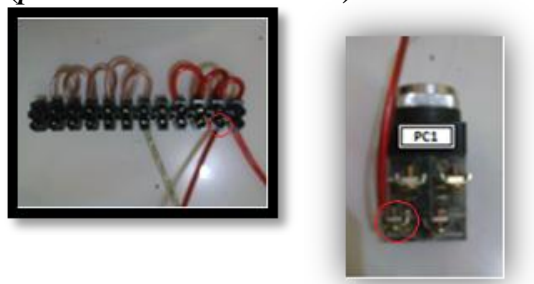

2. Keluran dari NO pada PC1 dihubungkan ke masukan coil RC (relay close) / terminal 13 dan keluran coil atau terminal 14 dihubungkan ke masukan NC pada PO1.
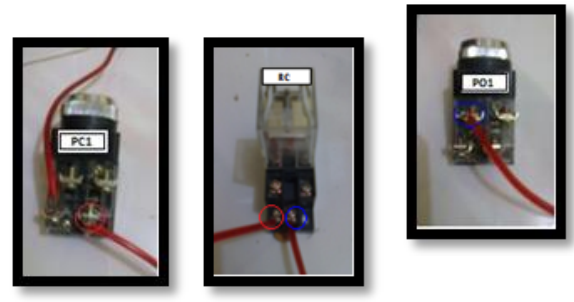

3. Keluran dari NO-PO1 dihubungkan dengan NO-PO2 dan kelurannya diteruskan ke limits switch LSC lalu langsung terhubung ke sumber arus negatif.
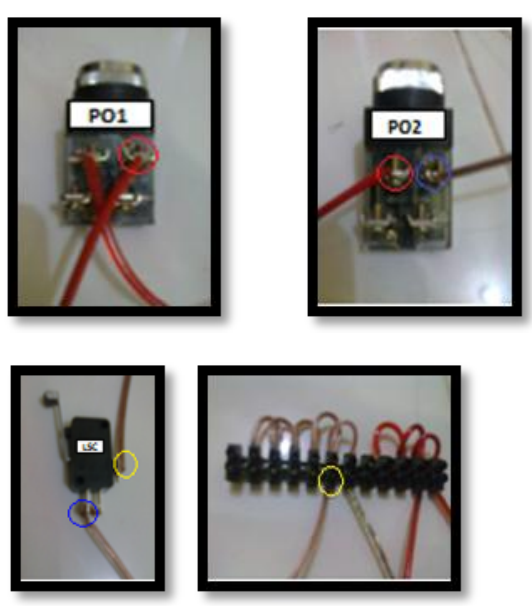

4. Terminal NC pada RC (termial 4) dihubungkan pada arus negatif.
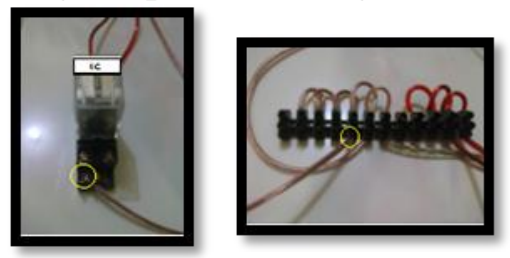

5. Terminal NO pada RC (terminal 8) dihubungkan pada arus positif.
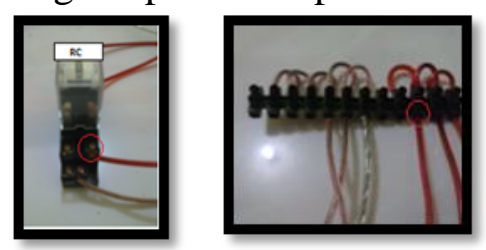

6. Terminal 12 pada RC dihubungkan dengan katup positif dari motor.

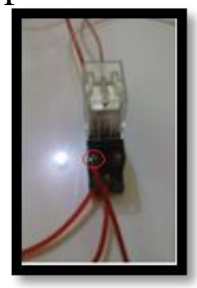

7. Terminal NO-PC1 dihubungkan ke terminal NO (5 - 9) pada relay RC.
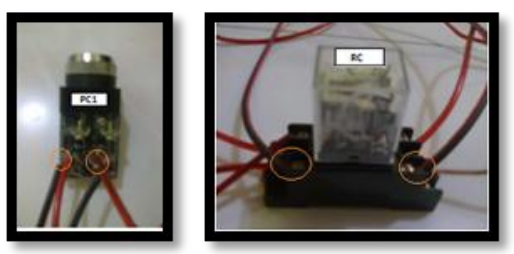

8. Terminal NO pada PC1 (push button close 1) dicouple dengan PC2 (push button close 2). 

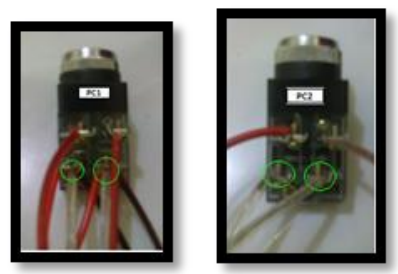

9. Arus positif dihubungkan dengan masukan NO pada PO1.
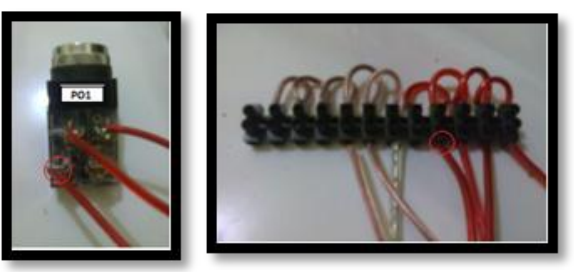

10. Keluran dari NO pada PO1 dihubungkan ke masukan coil RO (relay open) / terminal 13 dan keluran coil atau terminal 14 dihubungkan ke masukan NC pada PC1.
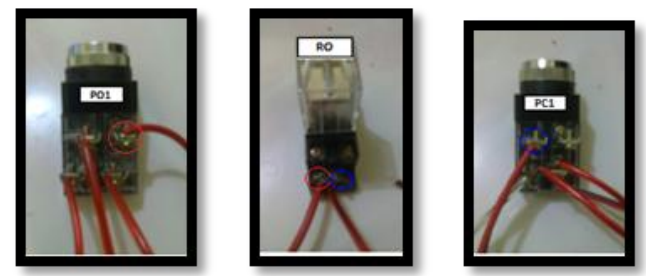

11. Keluran dari NO-PC1 selanjutnya dihubungkan dengan NO-PC2 dan kelurannya diteruskan ke limits switch LSO lalu langsung terhubung ke sumber arus negatif.

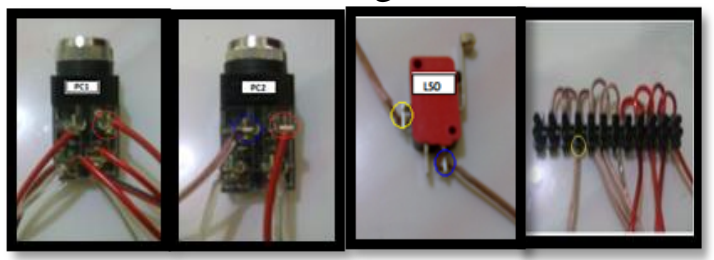

13. Terminal NC pada RO (termial 4) dihubungkan dengan arus negatif.

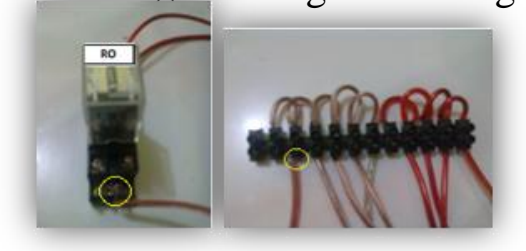

14. Terminal NO pada RO (terminal 8) dihubungkan pada arus positif.
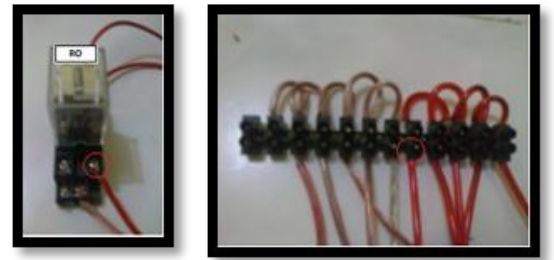

15. Teminal 12 pada RO dihubungkan dengan katup negatif dari motor, serta katup negatif dari central lock aktuator, katup positif dari central lock aktuator duhubungkan dengan arus negatif.
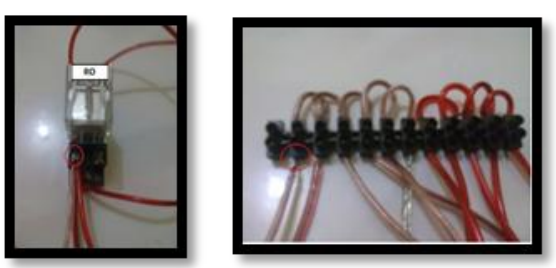

16. Terminal NO-PO1 dihubungkan ke terminal NO (5 - 9) pada relay RO.
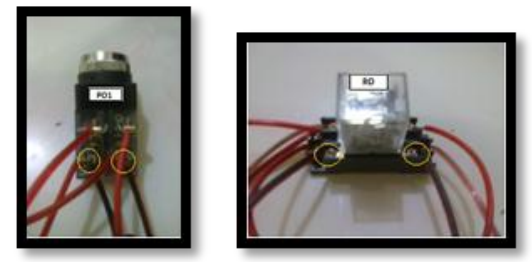

17. Terminal NO pada PO1 (push button open 1) dicouple dengan PO2 (push button open 2).

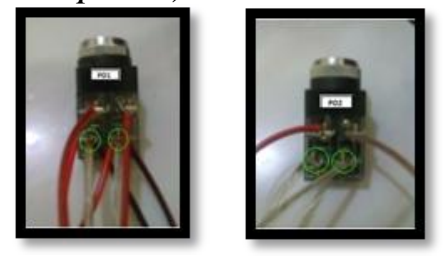

\section{SIMPULAN}

Kesimpulan yang dapat penulis ambil setelah selesai menyusun tugas akhir dengan judul Pembuatan Sistem Kontrol Sliding Door Untuk Rumah Tinggal ini adalah sebagai berikut :

1. Dalam pembutan rangkaian sistem kontrol pada sliding door untuk rumah tinggal penulis menggunakan rangkaian kontrol dengan sistem analog, serta sistem kontrol ini termasuk pada golongan sistem kontrol loop terbuka (open-loop), yang artinya pada sistem ini keluaran tidak ikut andil dalam aksi pengendalian

2. Komponen kontrol yang ddigunakan dalam pembuatan sistem kontrol ini terdiri dari 
a. Adaptor yang berfungsi sebagai media penurun tegangan arus listrik rumah tangga yang disalurkan ke sistem kontrol.

b. Push Button befungsi untuk penyambung dan pemutus arus pada sistem kontrol.

c. Relay berfungsi untuk mengontrol aliran listrik seperti menahan aliran atau arus listrik pada rangkaian listrik.

d. Limit Switch berfungsi sebagai pembatas gerak atau pemutus aliran listrik pada rangkaian kontrol.

e. Motor DC sebagai media penggerak untuk pintu

3. Sliding door untuk rumah tinggal yang digunakan saat ini pada kontruksinya masih terdapatnya kerenggangan antara pintu dan dinding pada saat pintu dalam kondisi tertutup sehingga menyebabkan adalanya celah udara untuk keluar masuk dengan bebas. Akan tetapi penulis mencoba untuk meminimalisir kondisi tersebut dengan membuat kondisi pintu akan sejajar dengan dinding sehingga udara tidak dapat keluar atau masuk ke ruangan dengan bebas.

\section{SARAN}

Beberapa saran yang ingin penulis berikan adalah

1. Dalam merangkai sistem kontrol kita harus terlebih dahulu mempelajari terlebih dahulu dasar dari rangkaian listrik, karena dengan menguasai dasar dari rangkaian listrik kita dapat dengan mudah membuat rangkaian kontrol itu sendiri.

2. Harus memahami terlebih dahulu fungsi dan cara kerja dari komponen kontrol yang akan kita gunakan.

Masukan aliran listrik dari sumber harus ke komponen harus sesuai dengan ketahanan dari komponen tersebut, seperti jika coil pada relay membutuhkan tegangan $12 \mathrm{~V}$, maka penyuplaian arus pada relay haruslah sesuai dengan ketentuan itu, karena jika berlebih akan menyebabkan coil pada relay akan rusak atau terbakar.

\section{DAFTAR PUSTAKA}

http://duniarumah.blogspot.com/2008/07/ macam-macam-jenis-pintu.html. Diakses Pada 2 Juli 2013.

http://akhdanazizan.com/tombol-tekanpush-button

Diakses Pada 4 Juli 2013.

http://www.elangsakti.com/2013/03/peng ertian-fungsi-prinsip-dan-cara.html

Diakses Pada 4 Juli 2013

http://elektronikadasar.web.id/komponen/limit-switchdan-saklar-push-on/

Diakses Pada 10 Juli 2013

http://www.meriwardanaku.com/2011/11 /prinsip-kerja-motor-arus-searahdc.html

Diakses Pada 20 Juli 2013

home-railsystem.blogspot.com

http://www.european-window.com

http://mastugino.blogspot.com/2012/12/r

angkaian-listrik.html

http://eviandrianimosy.blogspot. com

http//www.meriwardanaku.com

http://dunia-listrik.blogspot.com

http://delta-electronic.com

http://www.saft7.com

http://akhdanazizan.com

http://www.elangsakti.com)

http://elektronika-dasar.web.id)

http://www. bridgat.com

http://wwwkusenpintujendela.com

$\underline{w w w . d i r e c t i n d u s t r y . c o m}$

www.okefood.com,

www.fontrickdoor.com

$\underline{\text { www.arcat.com }}$

www.indonesian.welded-steelpipes.com 
